\title{
Improving Collection Development and Reference Services for Interdisciplinary Fields through Analysis of Citation Patterns: An Example Using Tourism Studies
}

\section{Juris Dilevko and Keren Dali}

Analyzing the citation characteristics of the scholarly production of an interdisciplinary field according to the kind of research methodology employed can provide much valuable information that can be used to improve both collection development decisions and reference services. Focusing on tourism studies, this article shows how a detailed breakdown of citations by Library of Congress (LC) classification can help librarians manage the information scatter that is typically associated with interdisciplinary fields. Data about the percentage of cited material from particular LC classes and subclasses that are used in the collective research output of an interdisciplinary field can be helpful in identifying types of material for purchase that otherwise may be overlooked. In addition, by identifying LC classes and subclasses that generate many citations, librarians can closely examine individual citations from these classes to get a detailed sense of how interdisciplinary scholars do their intellectual work, thus allowing them to better understand and anticipate the future information needs of these scholars.

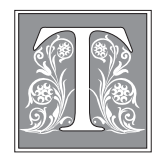

he existence of interdisciplinary academic endeavor should, by now, be a given. Scholars talk and collaborate with colleagues belonging to many disciplines and subdisciplines outside their own core areas. Working in groups or individually, they read widely in, and adopt insights from, diverse fields and subfields for use in their own research. In so doing, they hope to inform their work with contextual richness, new perspectives, and bold theories. Often new fields and subfields result from the process of interdisciplinary cross-fertilization. But interdisciplinarity is by no means easy because scholars must acculturate themselves in a subject area or areas with which they have very little familiarity. As Don Spanner observed in a study of

Juris Dilevko and Keren Dali are members of the faculty of Information Studies at the University of Toronto; e-mail: dilevko@fis.utoronto.ca and dali@fis.utoronto.ca. 
twenty-three Canadian interdisciplinary scholars, interdisciplinary work is much like "border crossings" - filled with tension, different cultural imperatives, and conflicting vocabularies. ${ }^{1}$ As interdisciplinarity evolves into an essential part of the knowledge system and structures of colleges and universities, librarians are faced with finding ways to adequately serve an increasingly interdisciplinary campus.

How best to do so? There have been attempts to understand the elements of the research processes of interdisciplinary scholars in the humanities and social sciences, but if any conclusion is to be drawn from such efforts, it is that almost every scholar has her or his complex and unique way of exploring, identifying, and using information sources. For example, Carole L. Palmer and Laura J. Neumann, in an analysis of the "information work" of twenty-five interdisciplinary scholars, commented on "the mutable intellectual course" followed by these scholars. "Paths of inquiry are long, unpredictable," thus leading to "a relatively unique path of information seeking for each project." ${ }^{2}$ In another study, Palmer, noting that "scientists and engineers need to know more than in the past if they wish to succeed in hybrid research areas," concluded that interdisciplinary researchers "use divergent information strategies" because they have many different abilities, temperaments, and backgrounds and because they are accustomed to using "different methods, techniques, and instrumentations" from their own fields. ${ }^{3}$

For librarians, such conclusions are of limited use. After all, most librarians are acutely aware that "[s]cholars scan large amounts of text to identify segments that intersect with their path of inquiry," that they "actively extend their intellectual province through information work," and that they have "developed a state of preparedness by maintaining a high level of interaction with a wide variety of information." ${ }^{4}$ For all intents and purposes, these are the basic components of the job description of any professor in any field. To help interdisciplinary scholars in a concrete way, librarians need more than generalities. They need to provide what Palmer referred to as "tools that function as boundary objects" - tools that enable scholars to probe more easily into "peripheral areas to increase their breadth of perspective and to generate new ideas." In other words, librarians need to manage information scatter in all its manifestations, whether in the spatial or intellectual organization of collections. ${ }^{6}$ In so doing, they can help scholars find "information leeway," defined as "a range of initiatives that make room for, or create the freedom to do, interdisciplinary work." 7 According to Lynn Westbrook, the development of such initiatives is of vital importance because many scholars in such interdisciplinary fields as women's studies, for example, stress that what they most need is "concrete support in exploring the issue at hand." ${ }^{8}$ Indeed, many of them assert that "I need a librarian to ask questions to get me to see my research focus in a different light" or a librarian who can help find "[a] way to conceptualize my problem ... talking through the idea and getting her response and knowledge." More than ever, librarians find themselves called upon to be proactive participants in interdisciplinary research pursuits.

\section{Purpose}

The purpose of this article is to make librarians aware that they can derive specific knowledge about the scholarly information needs of various interdisciplinary fields through an analysis of the citation characteristics of the research production of those fields. To be sure, analysis of citation characteristics is a time-honored 
bibliographic approach. But, as the authors of this study hope to show, it has the untapped potential to create content-rich road maps about the wide range of subject matter that interdisciplinary scholars discuss in their research. As a demonstration of this approach, the authors focus on tourism studies. They describe the current state of tourism studies based on analysis of citation characteristics of full-length research articles in two of the most important peer-reviewed journals in the field, paying particular attention to differences in citation characteristics according to the type of research methodology employed in the examined articles and disciplines/ fields of study, as determined by Library of Congress (LC) classification classes and subclasses. Data about the percentage of cited material from particular LC classes and subclasses that are used in an interdisciplinary field can be helpful in identifying not only the various kinds of subject matter used in that field, but also the way in which that subject matter is used by scholars. Closely examining individual citations from LC classes thus allows librarians to get a good sense of how interdisciplinary scholars do their intellectual work (i.e., make connections among disparate subject areas). This, in turn, will allow librarians to ask the kinds of questions that cause interdisciplinary scholars "to see [their] research focus in a different light." 10

A few words need to be said about tourism studies. Broadly speaking, tourism may be defined as "the movement of people for pleasure."11 The study of tourism - tourism studies - analyzes this movement as a "sociocultural phenomenon," understanding that tourism has become fully "instuitutionaliz[ed] in the everyday social fabric of peoples everywhere." 12 Tourism studies has gradually undergone a process of scientification in the period 1960-2000 as it has moved through four stages: advocatory; cautionary; adaptancy; and knowledge based. ${ }^{13}$ This last stage situates tourism studies as a social science, recognizing that " $[\mathrm{n}] \mathrm{o}$ single discipline alone can accommodate, treat, or understand tourism; it can be studied only if disciplinary boundaries are crossed and if multidisciplinary perspectives are sought and formed."14 Tourism studies thus draws upon a large number of fields, including anthropology, ecology, economics, history, psychology, and sociology, among others. ${ }^{15}$ But, as in many evolving academic areas, very little agreement exists on how to label tourism studies. Opinions vary about whether to call it a field or a discipline, or whether it is or is not a field or a discipline. ${ }^{16}$ Moreover, there are often bitter debates about the types of methodology to adopt in studying tourism and whether tourism studies lacks direction and maturity. ${ }^{17,18}$ As in other evolving academic areas, the very fact of its interdisciplinarity or multidisciplinarity is often held against tourism studies. In many ways, then, the relatively new interdisciplinary field of tourism studies resembles the relatively new interdisciplinary field of women's studies with regard to internal debates and issues. But whereas librarians are familiar with many of the issues surrounding women's studies in the university, they are less familiar with tourism studies. ${ }^{19}$

To portray the state of tourism studies in North America, the following research questions (RQ) were developed:

1. Which academic institutions in the United States and Canada have a significant number of scholars pursuing active research in tourism studies?

2. Which geographic regions are the most frequent subjects of tourism research studies?

3. What are the types of research methodologies most commonly used in tourism studies? 
4. What types of sources (e.g., articles, books, newspapers, reports, etc.) are most commonly used by tourism scholars, and how old are the sources they use?

5. What are the most frequently cited journal and book titles in tourism studies?

6. Do North American institutions that have a significant number of scholars pursuing active research in tourism own the most frequently cited journal and book titles in tourism studies?

7. What are the main disciplines/fields of study of the cited material used by tourism scholars, based on LC main classes and subclasses?

8. Are there any differences with regard to disciplines/fields of study of cited materials among different publication venues for tourism research?

9. Is there a relationship between the type of research methodology used in tourism studies and disciplines/fields of study of cited materials?

In general, the methodology described below and the research questions mentioned here can be applied to any evolving or evolved interdisciplinary field in order to create an objective portrait of that field's intellectual interconnections and tendencies that librarians can use in their collection development and reference work.

\section{Methodology}

As their initial sampling frame, the authors selected tourism and travel journals contained in the Journal Citation Reports (JCR) published by the Institute for Scientific Information (ISI). JCR is a selective index that, for its 2002 edition, included about 1,700 social science journals, and the journals selected for inclusion are deemed, whether rightly or wrongly, to be the most important in any given field..$^{20}$ Although there are many peer-reviewed journals in the field of tourism and travel (as well as in the related field of recreation and leisure), only two were contained in JCR when the present study was begun in November 2002: Annals of Tourism Research (ATR) and Tourism Management (TM). ${ }^{21}$ All issues for these two titles for the years 2000-2002 were included in the present study.22

Both titles are indexed in the Social Sciences Citation Index (SSCI), also published by ISI. For the years 2000-2002, SSCI indexed 272 items from ATR and 240 items from TM. The authors downloaded complete bibliographical information, including cited sources, from these 512 items into the EndNote bibliographic software program using the "Export to Reference Software" feature on the "Marked Records" page in SSCI. This became Bibliographical Database A. Downloaded items were classified by ISI as follows: article, review, book review, biographical item, editorial material, and correction. Only items designated in ISI as an article or a review were selected to form the basis of the present study because full-length research articles are the best indicators of interdisciplinary or multidisciplinary trends. In addition, all ISI designations were double-checked against full-text published items in ATR and TM. For instance, if an item designated by ISI as an article or review appeared in the journal itself as a research report or research note, it was excluded from the analysis. All items chosen for further analysis are therefore full-length research papers.

In total, there were 142 full-length research articles in ATR and 149 such articles in TM in the period 2000-2002. The authors then selected only those articles that had at least one author affiliated with a North American institution (United States or Canada). ${ }^{23}$ Theoretically, these are the authors in the field of tourism that would make use of North American library resources and have contact with North 
American librarians. As a result, the final set of full-length research articles used in the present study contained 80 articles -41 from ATR and 39 from TM. The geographic area to which the research pertained was recorded. ${ }^{24}$ Finally, each article was categorized according to its broad research methodological type: qualitative, quantitative, qualitative and quantitative, theoretical, or review. ${ }^{25}$ Relevant bibliographic information about the 80 articles from Bibliographical Database A was transferred into Bibliographical Spreadsheet A, relational links were made between them, and each article was assigned a unique identification (ID) number.

All citations appearing in these 80 articles were downloaded from the previously mentioned EndNote database into another Excel spreadsheet (Bibliographical Spreadsheet B) in the order in which they appeared in the ISI citation fields. ${ }^{26}$ Citations were numbered consecutively for each journal. There were 1,965 citations for ATR and 1,517 citations for TM. There were 3,482 total citations, 56.4 percent of which came from ATR and 43.6 percent from TM. A sample of 559 citations was drawn from this total; a sample of this size has a confidence level of 99 percent with a confidence interval of five (5). ${ }^{27}$ The number of citations to be sampled from each journal was determined based on the percentage of citations contributed by each journal to the total number of downloaded citations. From the sample of 559 citations, 315 (56.4\%) came from ATR and 244 (43.6\%) from TM. Random numbers for sampling were generated using the online statistical tool Research Randomizer. ${ }^{28}$

Complete bibliographic information for each of the 559 sampled citations was obtained from Online Computer Library Center (OCLC) databases such as WorldCat, PapersFirst, and Proceedings, ${ }^{29}$ and a complete record of each citation was exported from these OCLC sources into a second EndNote database. This became Bibliographical Database B. The following additional fields were created for each citation: type of source; ${ }^{30}$ LC classification of the discipline to which the citation belongs; ${ }^{31}$ and descriptive titles of the LC classes and subclasses from LC schedules. A unique ID was assigned to each citation. The authors then interlinked each of Bibliographical Spreadsheets A and B with Bibliographical Databases A and B through the assigned ID numbers. These linked databases and spreadsheets thus contained all necessary data to portray the state of tourism studies. The results reported below were obtained through a series of pivot tables on the linked databases and spreadsheets.

\section{Results}

Which colleges and universities in North American employ scholars producing the most research articles in tourism (RQ-1)? Based on analysis of author affiliations in ATR and TM, the top institutions for tourism research are: Virginia Tech (12); Texas A\&M (11); Northern Arizona (7); University of Central Florida, University of Illinois at Urbana-Champaign, and University of Nevada at Las Vegas (5 each); Arizona State, Iowa State, Purdue, University of Alberta, and University of Georgia (4 each); and University of Calgary, University of Washington, and Washington State (3 each).

With regard to the geographic regions that are the subjects of tourism research (RQ-2), the United States (either as a whole, individual states, U.S. tourists in other countries, interactions of U.S. tourists/hosts with people from other countries, etc.) is the central subject of 27 articles (33.8\%), and Canada is the central subject of seven articles (8.8\%). Latin America (Dominican Republic, Guatemala, Mexico, and Peru) and the 


\begin{tabular}{|l|c|c|c|c|}
\hline \multicolumn{5}{|c|}{ TABLE 1 } \\
Tourism Articles (from Annals of Tourism Research and Tourism \\
Management) by Type of Research and Research Methodology (n = 80)
\end{tabular}

Caribbean are researched in eight articles (10\%); Hong Kong, Japan, Korea, and Taiwan in seven $(8.8 \%)$; the Mediterranean countries (Egypt, Greece, Israel, Italy, and Turkey) in four (5\%); Australia, New Zealand, and African countries (Ghana, South Africa, and Tanzania) in three articles each (11.25\%); and Eastern Europe (Russia and Latvia) in two (2.5\%). Eight articles focus on multiple countries, including such combinations as the United States/South Africa, Sweden/Denmark/Germany, United States/Turkey, and "developing countries." Another eight articles are not linked to any specific region or country.

As shown in table 1, the majority of articles in ATR and TM use quantitative methods (47, or $58.8 \%)$; 11 are qualitative (13.8\%); eight (10\%) combine qualitative and quantitative methods; and 14 (17.5\%) are theoretical and/or review articles (RQ3). ATR hosts more qualitative research articles $(8$, or $19.5 \%)$ and qualitative-quantitative articles (7, or $17.1 \%)$ than does TM (1, or $2.6 \%$; 3 or $7.7 \%$, respectively). The percentage of theoretical/review articles is almost equal in the two publications ( 7 , or $17.1 \%$ in ATR; 7 , or $17.9 \%$ in TM), whereas the percentage of quantitative articles is much lower in ATR (19, or $46.3 \%)$ than in TM $(28$, or $71.8 \%)$.

Tourism scholarship relies to a great extent on other academic journals in its citations. As shown in table 2, academic 
journals comprise 50.1 percent of cited materials, with books at 20.2 percent. Reports and statistics are used only 4.3 percent of the time, whereas conference papers and proceedings $(3.8 \%)$ and Ph.D. dissertations (1.8\%) are used even less (RQ-4). To examine the distribution of citations by type of source in each of the two journals, the authors collapsed the fifteen categories shown in table 2 into nine categories. ${ }^{32}$ TM has a slightly higher percentage of citations than ATR in six categories: academic/scholarly journals $(129$, or $52.9 \%$ versus 151 , or $47.9 \%$ ); reports/statistics (13, or $5.3 \%$ versus 11 , or $3.5 \%$ ); consumer magazine/trade publication/newsletter (12, or $4.9 \%$ versus 11 , or $3.5 \%$ ); conference papers/conference proceedings (10, or $4.1 \%$ versus 11 , or $3.5 \%$ ); newspaper (print and online) and broadcast (11, or $4.5 \%$ versus 6 , or $1.9 \%$ ); and electronic resources $(2$, or $0.8 \%$ versus 1 , or $0.3 \%){ }^{33}$ Conversely, ATR has a slightly higher percentage of cited sources than does TM in three categories: books and edited books (94, or $29.8 \%$ versus 51 , or $20.9 \%$ ); book chapters (21, or $6.7 \%$ versus 14 , or 5.7\%); and Ph.D. dissertation/master's thesis $(9$, or $2.9 \%$ versus 2 , or $0.8 \%$ ).

As is the case with most physical sciences and social sciences researchers,

\begin{tabular}{|l|c|}
\hline \multicolumn{2}{|c|}{$\begin{array}{c}\text { TABLE 3 } \\
\text { Citations by Year of Publication } \\
\text { of Cited Source (n = 559) }\end{array}$} \\
\hline \hline $\begin{array}{l}\text { Years of } \\
\text { Publication }\end{array}$ & Number (\%)* \\
\hline $1900-1960$ & $6 \quad(1.1)$ \\
\hline $1961-1970$ & $8 \quad(1.4)$ \\
\hline $1971-1980$ & $50 \quad(8.9)$ \\
\hline $1981-1990$ & $159(28.4)$ \\
\hline $1991-1995$ & $180(32.2)$ \\
\hline $1996-2000$ & $145(25.9)$ \\
\hline 2001-2002 & $11 \quad(2)$ \\
\hline * Does not add to 100 because of rounding \\
\hline
\end{tabular}

\begin{tabular}{|c|c|}
\hline \multicolumn{2}{|c|}{$\begin{array}{c}\text { TABLE } 2 \\
\text { Citations by Type of Source Cited } \\
(n=559)\end{array}$} \\
\hline Type of Source & Number $(\%) *$ \\
\hline Academic/scholarly journal & $280(50.1)$ \\
\hline Book & $113(20.2)$ \\
\hline Book chapter & $35 \quad(6.3)$ \\
\hline Edited book & $32 \quad(5.7)$ \\
\hline Report or statistics & $24 \quad(4.3)$ \\
\hline Newspaper (print or online) & $16 \quad(2.9)$ \\
\hline Conference paper & $14 \quad(2.5)$ \\
\hline Trade publication & $13 \quad(2.3)$ \\
\hline Ph.D. dissertation & $10 \quad(1.8)$ \\
\hline Consumer magazine & $9 \quad(1.6)$ \\
\hline Conference proceedings & $7 \quad(1.3)$ \\
\hline Electronic resource & $3 \quad(0.5)$ \\
\hline Broadcast & $1 \quad(0.2)$ \\
\hline Master's thesis & $1 \quad(0.2)$ \\
\hline Newsletter & $1 \quad(0.2)$ \\
\hline
\end{tabular}

tourism scholars have a tendency to cite recent literature frequently (also RQ-4). There were more than twice as many citations to material published in the decade 1991-2000 (325) than in the decade 1981-1990 (159). As shown in table 3, the greatest frequency of citations in articles published in 2000-2002 in ATR and TM is to material that was published between 1991 and 1995. The absolute peak years for cited material were 1993-1998. ${ }^{34}$

Twenty-three academic journals, fourteen book titles, two consumer magazines/trade publications, and two newspapers were cited more than once in the citations studied here, and these are listed in descending order in table 4 . Taken together, these publications could be said to comprise the core of tourism research literature (RQ-5).$^{35}$ Within the set of 23 academic journals, one finds such titles as American Sociological Review, Psy- 


\begin{tabular}{|c|c|}
\hline \multicolumn{2}{|r|}{$\begin{array}{l}\text { TABLE } 4 \\
\text { Titles Cited More than Once by Type of Source }\end{array}$} \\
\hline Type of source & Title (times cited) \\
\hline $\begin{array}{l}\text { Academic journal } \\
(23)\end{array}$ & $\begin{array}{l}\text { Annals of Tourism Research (83) } \\
\text { Journal of Travel Research (48) } \\
\text { Tourism Management (13) } \\
\text { Journal of Marketing (7) } \\
\text { JMR, Journal of Marketing Research (6) } \\
\text { Leisure Sciences (6) } \\
\text { Journal of Leisure Research (5) } \\
\text { Journal of Consumer Research (4) } \\
\text { Tourism Analysis (4) } \\
\text { European Journal of Marketing (3) } \\
\text { Journal of Travel \& Tourism Marketing (3) } \\
\text { Journal of Vacation Marketing (3) } \\
\text { Psychological Bulletin (3) } \\
\text { Cornell Hotel and Restaurant Administration Quarterly (3) } \\
\text { American Sociological Review (2) } \\
\text { Australian Journal of Hospitality Management (2) } \\
\text { Forum for Applied Research and Public Policy (2) } \\
\text { Journal of Park and Recreation Administration (2) } \\
\text { Journal of Sustainable Tourism (2) } \\
\text { Journal of the Academy of Marketing Science (2) } \\
\text { Theory, Culture \& Society (2) } \\
\text { Tourism Recreation Research (2) } \\
\text { Wildlife Society Bulletin (2) }\end{array}$ \\
\hline $\begin{array}{l}\text { Book } \\
\text { book for cited } \\
\text { book chapters, } \\
\text { edited book (14) }\end{array}$ & $\begin{array}{l}\text { Hosts and Guests: The Anthropology of Tourism (4) } \\
\text { Tourism: Principles, Practices, Philosophies (3) } \\
\text { The Business of Rural Tourism: International Perspectives (2) } \\
\text { Ethnic and Tourist Arts: Cultural Expressions from the Fourth } \\
\text { World (2) } \\
\text { The Golden Hordes: International Tourism and the Pleasure Pe- } \\
\text { riphery (2) } \\
\text { Handbook of Qualitative Research (2) } \\
\text { Naturalistic Inquiry (2) } \\
\text { Principles of Marketing (2) } \\
\text { The Tourist: A New Theory of the Leisure Class (2) } \\
\text { Tourism Analysis: A Handbook (2) } \\
\text { Tourism and Sustainable Development: Monitoring, Planning, } \\
\text { Managing (2) } \\
\text { Tourism, Ethnicity, and the State in Asian and Pacific Societies (2) } \\
\text { Travel, Tourism, and Hospitality Research: A Handbook for Manag- } \\
\text { ers and Researchers (2) } \\
\text { The Sociology of Tourism: Theoretical and Empirical Investigations } \\
\text { (2) }\end{array}$ \\
\hline Newspaper (2) & $\begin{array}{l}\text { Miami Herald (7) } \\
\text { New York Times (3) }\end{array}$ \\
\hline $\begin{array}{l}\text { Consumer } \\
\text { magazine or trade } \\
\text { publication }(2)\end{array}$ & $\begin{array}{l}\text { Canadian Geographic (2) } \\
\text { Ski Area Management (2) }\end{array}$ \\
\hline
\end{tabular}


chological Bulletin, and Theory, Culture $\mathcal{E}$ Society. In addition, there are 71 academic journals that are cited only once. These 71 journals represent a diverse array of interests: American Anthropologist, Clothing and Textile Research Journal, International Journal of Intercultural Relations, Journal of American Folklore, Journal of Asian Studies, Journal of Peasant Studies, Public Opinion
Quarterly, Qualitative Sociology, Religion, Sexuality \& Culture, and the Yale Journal of Regulation, to mention only a few. Of the fourteen books, eleven are tourism specific and three are from the areas of philosophy, research methodology, or marketing.

Do the six libraries in the United States and Canada whose universities employ

\begin{tabular}{|c|c|c|}
\hline \multicolumn{3}{|c|}{$\begin{array}{c}\text { TABLE } 5 \\
\text { Citations by Discipline Based on LC Classes and Subclasses (Broad } \\
\text { Disciplines and Fields of Study within a Discipline) }(\mathbf{n}=\mathbf{5 5 9})\end{array}$} \\
\hline $\begin{array}{l}\text { LC Main Class/ } \\
\text { Subclass Letters }\end{array}$ & $\begin{array}{c}\text { Disciplines and Fields of Study within a Discipline } \\
\text { (descriptions based on LC main/subclass titles) }\end{array}$ & $\begin{array}{c}\text { Number of } \\
\text { Citations (\%) }\end{array}$ \\
\hline G149-550 & Travel \& Tourism & $253(45.3)$ \\
\hline GV & Recreation \& Leisure & $33 \quad(5.9)$ \\
\hline $\begin{array}{l}\text { H, HA, HB, HC, } \\
\text { HD, HE, HF, HG }\end{array}$ & $\begin{array}{l}\text { Social Sciences (General). Statistics. Economics. } \\
\text { Industries and Industrial Management. Agricultural } \\
\text { Classes. Transportations and Communications. Com- } \\
\text { merce. Business. Marketing. Finance }\end{array}$ & $89(15.9)$ \\
\hline $\begin{array}{l}\text { HM, HN, HQ, } \\
\text { HT, HV }\end{array}$ & $\begin{array}{l}\text { Sociology. Social History and conditions. Social prob- } \\
\text { lems. Social reforms. The family. Marriage. Women. } \\
\text { Communities. Classes. Races. Social pathology. Social } \\
\text { and public welfare. Criminology }\end{array}$ & $(7.7)$ \\
\hline $\begin{array}{l}\text { QA, QH, R, S, } \\
\text { SB, SD, SK, T, } \\
\text { TL, TP, TS, TX, } \\
\text { UF }\end{array}$ & $\begin{array}{l}\text { Science. Medicine. Agriculture. Technology. Military } \\
\text { Science }\end{array}$ & $32 \quad(5.7)$ \\
\hline $\begin{array}{l}\text { CB, DA, DK, } \\
\text { DS, E, F }\end{array}$ & $\begin{array}{l}\text { History of Civilization. History (General) and History } \\
\text { of Europe (History of Great Britain. History of Rus- } \\
\text { sia. Soviet Union. Former Soviet Republics. History } \\
\text { of Asia.) History: America (America. United States. } \\
\text { United States local history. British America (includ- } \\
\text { ing Canada). Dutch America. French America. Latin } \\
\text { America. Spanish America) }\end{array}$ & (5) \\
\hline AN, AP, AZ & $\begin{array}{l}\text { General Works (Newspapers. Periodicals. History of } \\
\text { scholarship and learning. The humanities) }\end{array}$ & $22 \quad(3.9)$ \\
\hline $\mathrm{B}, \mathrm{BD}, \mathrm{BF}, \mathrm{BL}$ & Philosophy. Psychology. Religion & $(3.6)$ \\
\hline GF, GN, GR & $\begin{array}{l}\text { Human ecology. Anthropogeography. Anthropology. } \\
\text { Folklore. }\end{array}$ & $(3.2)$ \\
\hline $\begin{array}{l}\text { G (excludes } \\
149-550), \text { GB, } \\
\text { GC, GE }\end{array}$ & $\begin{array}{l}\text { Geography (General). Physical geography. Oceanogra- } \\
\text { phy. Environmental sciences }\end{array}$ & $(1.4)$ \\
\hline $\mathrm{N}, \mathrm{P}, \mathrm{PK}, \mathrm{PN}$ & Fine Arts, Languages and Literatures & $7 \quad(1.3)$ \\
\hline $\begin{array}{l}\text { K, KF, KJA, KZ, } \\
\text { LB }\end{array}$ & Law. Education & $6 \quad(1.1)$ \\
\hline
\end{tabular}


tourism scholars who published five or more times in ATR and TM have the 23 core academic journals and 14 book titles in their collections (RQ-6)? ${ }^{36}$ Four of these six universities have 20 or more of the 23 core academic journals in their library systems, with the University of Nevada at Las Vegas having the most (22) and the University of Central Florida (17) and Northern Arizona University (14) the least. Four of the six universities have 13 or 14 of the 14 core books in their libraries, with the University of Nevada at Las Vegas and the University of Illinois at Urbana-Champaign having the most (14) and Northern Arizona University (11) and the University of Central Florida (11) the least. Twelve of the 23 journals were held by all six libraries. The least frequently held journals were Tourism Recreation Research (2) and Journal of Vacation Marketing (1). Thirteen of the 14 book titles were held by either five or six libraries; only one title, The Business of Rural Tourism: International Perspectives, was infrequently held (2 libraries).

Tourism scholars make use of citations from a wide variety of disciplines/fields of study (RQ-7). As shown in table 5, citations from within the field of travel and tourism itself or the related field of recreation and leisure (i.e., what we call tourism disciplines) comprise 51.2 percent of all citations. Citations from diverse other fields, ranging from anthropology to economics to history to literature to medicine to psychology to sociology (collectively called nontourism disciplines), make up 48.8 percent of the citations (table 5). A closer examination of the citations from the nontourism disciplines shows that tourism is being researched as both "a trade or an industry" and "a sociocultural phenomenon." ${ }^{37}$ Of the 273 citations from nontourism disciplines, 89 $(32.6 \%)$ are, broadly speaking, from business, economics, and finance; 43 (15.8\%) from sociology; 32 (11.7\%) from science and medicine; 28 (10.3\%) from history; 20 (7.3\%) from philosophy and psychology; $18(6.6 \%)$ from anthropology; seven $(2.6 \%)$ from arts and literature; and six $(2.2 \%)$ from education and law. ${ }^{38}$ These broad disciplines are, of course, composed of numerous subfields. A listing of the LC main class and subclass titles of some of these non-tourism disciplines indicates that tourism studies is a tremendously rich interdisciplinary field, substantiating the findings of tourism scholars themselves. ${ }^{39}$ (See tables 6 and 7.)

Are there any major differences in the distribution of citations between ATR and TM from the perspective of LC disciplines/fields of study from which citations are derived (RQ-8)? The percentage of citations derived from travel and tourism and recreation and leisure is just slightly higher in TM (53.2\%) than in ATR (49.5\%). Thus, although both journals derive about half of their citations from nontourism disciplines (ATR at a rate of $50.5 \%$ and TM at a rate of $46.8 \%$ ), there are some slight differences in the distribution of those disciplines. For example, ATR derives, in absolute terms, 2.8 percent more citations from American history (LC class F) and 4.9 percent more citations from sociology (LC subclasses HM, HN, HQ, HT, and HV) than TM. Conversely, TM derives, in absolute terms, 3.4 percent more citations from the field of business and commerce (LC subclasses HF and HG) than ATR. Both journals derive citations from all other nontourism disciplines at virtually indistinguishable rates (less than $0.5 \%$ ).

There are larger differences in the nature of citations that are used by different research methods within tourism (RQ-9). As shown in table 8, theoretical or review articles draw 66.2 percent of their citations from nontourism disciplines and qualitatively based articles draw 58.2 percent of their citations from nontourism 


\begin{tabular}{|c|c|c|}
\hline \multicolumn{3}{|c|}{$\begin{array}{c}\text { TABLE } 6 \\
\text { Citations by Fields of Study within Nontourism Disciplines (Class H) }\end{array}$} \\
\hline $\begin{array}{l}\text { LC Main } \\
\text { Class/Sub- } \\
\text { class Letters }\end{array}$ & $\begin{array}{l}\text { Disciplines and Fields of Study within a Discipline } \\
\text { (descriptions based on LC main/subclass titles) }\end{array}$ & $\begin{array}{l}\begin{array}{l}\text { Number } \\
\text { of } \\
\text { Citations }\end{array} \\
\end{array}$ \\
\hline $\mathrm{H}$ & Social sciences (General) & 12 \\
\hline HA & $\begin{array}{l}\text { Statistics; Theory and method of social science statistics; } \\
\text { Statistical data; By region or country }\end{array}$ & 4 \\
\hline HB & $\begin{array}{l}\text { Economic theory. Demography; Methodology; Mathematical } \\
\text { economics. Quantitative methods including econometrics, } \\
\text { input-output analysis, game theory }\end{array}$ & 4 \\
\hline $\mathrm{HC}$ & $\begin{array}{l}\text { Economic history and conditions; Special topics including air } \\
\text { pollution, automation, consumer demand, famines, flow of } \\
\text { funds, etc.; By region or country }\end{array}$ & 7 \\
\hline HD & $\begin{array}{l}\text { Industries. Land use. Labor; Management. Industrial manage- } \\
\text { ment; Organizational behavior, change and effectiveness. } \\
\text { Corporate culture; Management of special enterprises; Other } \\
\text { including business consultants, capacity, size of industries, } \\
\text { etc.; Economic growth, development, planning; Agricultural } \\
\text { classes including farm tenancy, agricultural laborers; Corpora- } \\
\text { tions including international business enterprises, diversi- } \\
\text { fication, industrial concentration, public utilities; Special } \\
\text { industries and trades; Agricultural industries }\end{array}$ & 16 \\
\hline $\mathrm{HE}$ & $\begin{array}{l}\text { Transportation and communications; Air transportation. } \\
\text { Airlines }\end{array}$ & 4 \\
\hline $\mathrm{HF}$ & $\begin{array}{l}\text { Commerce; Commercial geography. Economic geography; } \\
\text { Business; Marketing. Distribution of products }\end{array}$ & 39 \\
\hline \multirow[t]{2}{*}{ HG } & Finance; Investment, capital formation, speculation & 3 \\
\hline & Total & 89 \\
\hline HM & $\begin{array}{l}\text { Sociology (General; History of sociology. History of socio- } \\
\text { logical theory; Theory. Method. Relations to other subjects; } \\
\text { Culture; Social change; Social psychology }\end{array}$ & 17 \\
\hline $\mathrm{HN}$ & $\begin{array}{l}\text { Social history and conditions. Social problems. Social reform; } \\
\text { By region or country }\end{array}$ & 9 \\
\hline HQ & $\begin{array}{l}\text { The Family. Marriage. Women; Sexual life; Sex instruction } \\
\text { and sexual ethics; Prostitution; The family. Marriage. Home; } \\
\text { Single people }\end{array}$ & 5 \\
\hline HT & $\begin{array}{l}\text { Communities. Classes. Races; Urban groups. The city. Urban } \\
\text { sociology; City planning; Regional planning; Rural groups. } \\
\text { Rural sociology; Classes; Caste system; Races Including race } \\
\text { as a social group and race relations in general }\end{array}$ & 8 \\
\hline \multirow[t]{2}{*}{$\mathrm{HV}$} & $\begin{array}{l}\text { Social pathology. Social and public welfare. Criminology; } \\
\text { Alcoholism. Intemperance. Temperance reform; Criminology; } \\
\text { Crimes and offences }\end{array}$ & 4 \\
\hline & Total & 43 \\
\hline
\end{tabular}




\begin{tabular}{|c|c|c|}
\hline \multicolumn{3}{|c|}{$\begin{array}{c}\text { TABLE } 7 \\
\text { Citations by Fields of Study within Selected Nontourism Disciplines }\end{array}$} \\
\hline $\begin{array}{l}\text { LC Main } \\
\text { Class/Sub- } \\
\text { class Letters }\end{array}$ & $\begin{array}{l}\text { Disciplines and Fields of Study within a Discipline } \\
\text { (descriptions based on LC main/subclass titles) }\end{array}$ & $\begin{array}{l}\text { Number } \\
\text { of } \\
\text { Citations }\end{array}$ \\
\hline $\mathrm{CB}$ & Auxiliary Sciences of History. History of Civilization. & 2 \\
\hline DA & History of Great Britain. Description and travel. Guidebooks & 1 \\
\hline DK & $\begin{array}{l}\text { History of Russia. Soviet Union. Former Soviet Republics. Lo- } \\
\text { cal history and description. Baltic States }\end{array}$ & 1 \\
\hline DS & $\begin{array}{l}\text { History of Asia. (China; East Asia. The Far East; India } \\
\text { (Bharat). Local history and description.; Israel (Palestine). The } \\
\text { Jews. Ethnography. Tribes of Israel; Japan) }\end{array}$ & 7 \\
\hline $\mathrm{E}$ & $\begin{array}{l}\text { United States (General). Elements in the population. Afro- } \\
\text { Americans. }\end{array}$ & 6 \\
\hline \multirow[t]{2}{*}{$\mathrm{F}$} & $\begin{array}{l}\text { Latin America. Spanish America. Mexico. Antiquities. Indians; } \\
\text { Central America. Guatemala.; South America. Peru; British } \\
\text { America. Canada. Alberta. Ontario; Caribbean area. Caribbean } \\
\text { SeUnited States local history. New Southwest. Colorado River, } \\
\text { Canyon, and Valley. New Mexico }\end{array}$ & 11 \\
\hline & Total & 28 \\
\hline B & $\begin{array}{l}\text { Philosophy (General); Modern; Special topics and schools of } \\
\text { philosophy }\end{array}$ & 4 \\
\hline $\mathrm{BD}$ & Speculative philosophy; Epistemology. Theory of knowledge & 1 \\
\hline $\mathrm{BF}$ & $\begin{array}{l}\text { Psychology; Philosophy. Relation to other topics; Psycho- } \\
\text { analysis; Experimental psychology; Consciousness. Cognition } \\
\text { Including learning, attention, comprehension, memory, imagi- } \\
\text { nation, genius, intelligence, thought and thinking, psycholin- } \\
\text { guistics, mental fatigue; Affection. Feeling. Emotion; Applied } \\
\text { psychology }\end{array}$ & 14 \\
\hline \multirow[t]{2}{*}{$\mathrm{BL}$} & Religions. Mythology. Rationalism; Religion (General) & 1 \\
\hline & Total & 20 \\
\hline GF & Human ecology. Anthropogeography & 4 \\
\hline GN & $\begin{array}{l}\text { Anthropology; Ethnology. Social and cultural anthropol- } \\
\text { ogy; Culture and cultural processes Including social change, } \\
\text { structuralism, diffusion, etc.; Collected ethnographies; Applied } \\
\text { anthropology; Economic organization. Economic anthropol- } \\
\text { ogy; Social organization; Societal groups, ethnocentrism, } \\
\text { diplomacy, warfare, etc. }\end{array}$ & 13 \\
\hline \multirow[t]{2}{*}{ GR } & Folklore & 1 \\
\hline & Total & 18 \\
\hline $\mathrm{N}$ & Fine Arts. Visual arts. History & 2 \\
\hline $\mathrm{P}$ & $\begin{array}{l}\text { Language and Literature. Philology. Linguistics. Communica- } \\
\text { tion. Mass media. Oral communication. Speech }\end{array}$ & 1 \\
\hline PK & Indo-Iranian philology and literature & 1 \\
\hline
\end{tabular}


TABLE 7

Citations by Fields of Study within Selected Nontourism Disciplines

\begin{tabular}{|l|l|c|}
\hline \hline $\begin{array}{l}\text { LC Main } \\
\text { Class/Sub- } \\
\text { class Letters }\end{array}$ & \multicolumn{1}{|c|}{\begin{tabular}{c}
\multicolumn{1}{c}{$\begin{array}{c}\text { Disciplines and Fields of Study within a Discipline } \\
\text { (descriptions based on LC main/subclass titles) }\end{array}$} \\
\hline PN
\end{tabular}} & $\begin{array}{c}\text { Number } \\
\text { of } \\
\text { Citations }\end{array}$ \\
\hline & $\begin{array}{l}\text { Literature. Literary history. Collections; Drama. Broadcasting. } \\
\text { Television broadcasts }\end{array}$ & 3 \\
\hline Kotal & $\begin{array}{l}\text { Law in general. Comparative and uniform law. Jurisprudence. } \\
\text { Periodicals }\end{array}$ & $\mathbf{7}$ \\
\hline KF & $\begin{array}{l}\text { Law of the United States. Federal law. Common and collective } \\
\text { state law }\end{array}$ & 1 \\
\hline KJA & Law. Europe. Roman law & 1 \\
\hline KZ & Law of nations. International law and other disciplines & 1 \\
\hline LB & Education. Theory and practice of education. Higher education & 1 \\
\hline & Total & $\mathbf{6}$ \\
\hline
\end{tabular}

disciplines. Conversely, quantitatively based articles use citations from nontourism disciplines at a rate of 37.6 percent. The most popular nontourism LC class ranges from which quantitatively based articles draw their 108 citations are $\mathrm{H}$ HG (51, or $47.2 \%)$, QA-TX (18, or $16.7 \%)$, HM-HV (14, or $13 \%)$, and BF (10, or 9.3\%). On the other hand, the most popular LC classes from which qualitatively based articles draw their 39 citations are DS-F (10, or $25.6 \%)$, H-HG $(8,20.5 \%)$, HM-HV (7, or $17.9 \%)$, and GN-GR (4, or $10.3 \%$ ). Theoretical and review articles draw their 104 citations most frequently from $\mathrm{H}-\mathrm{HG}$ (25, or $24 \%), \operatorname{HM}-\mathrm{HV}(17$, or $16.3 \%)$, and A-AZ (16, or $15.4 \%)$. Articles making use of both qualitative and quantitative methods draw their 22 citations most frequently from H-HG (5, or $22.7 \%$ ) and HM-HV (5, or $22.7 \%$ ).

No matter their preferred research methodology, all tourism articles make substantial use of social sciences (Class $\mathrm{H})$ materials (i.e., sources in economics, finance, business, management, and marketing, on the one hand, and sociology and community studies, on the other) with varying degrees of emphasis. There are pronounced differences, however, in their use of such broad fields as history and anthropology and human ecology. Whereas quantitatively based articles use history citations (7) at a rate of 6.5 percent and anthropology and human ecology citations (3) at a rate of 2.8 percent, qualitatively based articles use history citations 25.6 percent of the time (10) and anthropology citations 10.3 percent of the time (4). Theoretical and review articles fall somewhere in the middle between qualitatively and quantitatively based research, using anthropology and human ecology citations (9) at a rate of 8.7 percent and history citations (11) at a rate of 10.6 percent. Tables 9 through 11 show selected subfields from which qualitative, quantitative, and theoretical or review articles draw their citations.

\section{Discussion}

These findings confirm that tourism scholars make significant use of sources outside their own discipline, drawing on such diverse areas as anthropology, history, psychology, and sociology at a 


\begin{tabular}{|l|c|c|c|}
\hline \multicolumn{4}{|c|}{ TABLE 8 } \\
Citations by Type of Discipline and by Type of Research \\
in Which They Were Used
\end{tabular}

rate of 48.8 percent (table 5). Studying tourism citations from 1994-1996, Richard M. Howey and colleagues found that 77.3 percent of citations in six tourism and hospitality journals came from other sources, although they did not define what they meant by "other sources." 40 One explanation for this divergence may be that even in the short period between 1996, the last year covered by Howey's study, and 2000, the first year covered by this study, tourism research has had an increasing body of its own tourism studies to draw upon. This is a natural development in the evolution of a discipline, especially a relatively young one such as tourism. A greater reliance on within-discipline citations may therefore be seen as one indication of professional solidification in a specific discipline. Still, a discipline that continues to cite other disciplines at a rate of 48.8 percent is one that is intellectually vibrant and outward-looking, alert to the intellectual insights of numerous other fields. As well, North American tourism scholars are doing work about a wide variety of geographic areas (e.g., Turkey, Ghana, Japan, etc.), a circumstance that contributes to their need for research material from nontourism disciplines and fields.

The findings also emphasize the fact that whereas about half of cited tourism material takes the form of academic journal articles (table 2), the other half comes from a wide array of sources, most of which are less than ten years old (table 3). Tourism also has core sources, as listed in table 4 . In addition, based on the results of author affiliation data, librarians can become aware of the names of other universities housing productive tourism researchers. Knowledge of this kind might be invaluable in suggesting networking or collaboration possibilities to a tourism scholar and in establishing links between and among subject-specialty librarians serving tourism scholars.

But perhaps the most important way that librarians can use the kind of detailed knowledge derived from an analysis of citation characteristics to provide better service to tourism researchers is to become more cognizant of the relationship between the type of research methodology used in a particular tourism article and the LC class areas that are typically associated with that type of methodology. Collection development librarians who are responsible for tourism can closely examine the findings in table 5 to get a sense of how they should broadly allocate their tourism collection development budget. In general, they should be spending only about 51.2 percent of their budget on material that is traditionally thought of as pertaining to the disciplines of tourism and recreation, while allocating about 15.9 percent on $\mathrm{H}-\mathrm{HG}$ class material, 7.7 percent on HM-HV material, 5.7 percent on QA-UF material, and so on. Moreover, depending on the most common types of 
research methodologies used by scholars at their institutions' tourism departments, collection development librarians can fine-tune their collection development acquisitions even more. For example, as shown in table 9, 9.3 percent of the citations in quantitatively based research articles are from psychology; as shown in table 10, 25.6 percent of the citations in qualitatively based research articles are from history; and as shown in table 11, 8.7 percent are from anthropology and human ecology. A library at an institution where tourism department researchers typically employ one type of research methodology may wish to proportionally increase its purchases in those LC class areas that are associated with that methodology.

For librarians serving tourism researchers, the information contained in tables 9 through 11 is equally compelling because it can allow them to investigate in detail how tourism scholars use individual citations from various LC classes and subclasses. Accordingly, tables 9 through 11 are the end result of an intellectual model that maps a given discipline/field

\begin{tabular}{|c|c|c|}
\hline \multicolumn{3}{|c|}{$\begin{array}{c}\text { TABLE 9 } \\
\text { Examples of Nontourism Disciplines and Fields of Study from Which } \\
\text { Quantitative Research Articles Draw Their Citations (108) }\end{array}$} \\
\hline $\begin{array}{l}\text { LC Main Class/Subclass } \\
\text { Letters \& Selected Class/ } \\
\text { Broad Subclass Titles }\end{array}$ & $\begin{array}{l}\text { Description of Disciplines/Fields } \\
\text { of Studies Based on LC Class/ } \\
\text { Subclass Titles }\end{array}$ & $\begin{array}{l}\text { Number of Citations } \\
\text { from LC Class/ } \\
\text { Subclass }\end{array}$ \\
\hline \multirow{7}{*}{$\begin{array}{l}\text { HM_Sociology (General). } \\
\text { Social psychology } \\
\text { HN-Social history and } \\
\text { conditions. Social problems. } \\
\text { Social reform } \\
\text { HT_Communities. Classes. } \\
\text { Races } \\
\text { HV-Social pathology. } \\
\text { Social and public welfare. } \\
\text { Criminology (14) }\end{array}$} & Sociology (General) & 3 \\
\hline & Social change & 1 \\
\hline & Social psychology & 4 \\
\hline & $\begin{array}{l}\text { Sociology. Social history and } \\
\text { conditions. Social problems. Social } \\
\text { reform. By region or country }\end{array}$ & 3 \\
\hline & $\begin{array}{l}\text { Communities. Classes. Races. } \\
\text { Urban groups. The city. Urban } \\
\text { sociology. City planning }\end{array}$ & 1 \\
\hline & $\begin{array}{l}\text { Communities. Classes. Races. } \\
\text { Urban groups. The city. Urban } \\
\text { sociology. Regional planning }\end{array}$ & 1 \\
\hline & $\begin{array}{l}\text { Social pathology. Social and public } \\
\text { welfare. Criminology. Crimes and } \\
\text { offenses }\end{array}$ & 1 \\
\hline \multirow{5}{*}{ BF-Psychology (10) } & Psychology & 3 \\
\hline & Affection. Feeling. Emotion & 2 \\
\hline & Applied psychology & 2 \\
\hline & Consciousness. Cognition & 2 \\
\hline & Experimental psychology & 1 \\
\hline \multirow{2}{*}{$\begin{array}{l}\mathrm{K} \text { - Law in general. Com- } \\
\text { parative and uniform law. } \\
\text { Jurisprudence } \\
\text { KZ-Law of nations (2) }\end{array}$} & $\begin{array}{l}\text { Law. Law in general. Comparative } \\
\text { and uniform law. Jurisprudence. } \\
\text { Periodicals }\end{array}$ & 1 \\
\hline & $\begin{array}{l}\text { Law. Law of nations. International } \\
\text { law and other disciplines }\end{array}$ & 1 \\
\hline
\end{tabular}




\begin{tabular}{|c|c|c|}
\hline \multicolumn{3}{|c|}{$\begin{array}{c}\text { TABLE } 10 \\
\text { Examples of Nontourism Disciplines and Fields of Study from Which } \\
\text { Qualitative Research Articles Draw Their Citations (39) }\end{array}$} \\
\hline $\begin{array}{l}\text { LC Main Class/Subclass } \\
\text { Letters \& Selected Class/ } \\
\text { Broad Subclass Titles }\end{array}$ & $\begin{array}{c}\text { Description of Disciplines/Fields } \\
\text { of Studies Based on LC Class/ } \\
\text { Subclass Titles }\end{array}$ & $\begin{array}{c}\text { Number of Citations } \\
\text { from LC Class/ } \\
\text { Subclass }\end{array}$ \\
\hline \multirow{7}{*}{$\begin{array}{l}\text { DS-History (General). } \\
\text { History of Asia } \\
\text { E, F-History: America } \\
\text { E-America. United States } \\
\text { F-United States local } \\
\text { historyBritish America } \\
\text { (including Canada) } \\
\text { Latin America. } \\
\text { Spanish America (10) }\end{array}$} & $\begin{array}{l}\text { History of Asia. East Asia. The Far } \\
\text { East }\end{array}$ & 1 \\
\hline & $\begin{array}{l}\text { History of Asia. India (Bharat). Lo- } \\
\text { cal history and description }\end{array}$ & 1 \\
\hline & History of Asia. Japan & 3 \\
\hline & America. Indians of North America & 1 \\
\hline & $\begin{array}{l}\text { United States. Elements in the } \\
\text { population. Afro-Americans }\end{array}$ & 1 \\
\hline & $\begin{array}{l}\text { British America. Canada/British } \\
\text { America. Canada. Ontario }\end{array}$ & 2 \\
\hline & $\begin{array}{l}\text { Latin America. Central America. } \\
\text { Guatemala }\end{array}$ & 1 \\
\hline \multirow{5}{*}{$\begin{array}{l}\text { H-Social Sciences } \\
\text { HM-Sociology (General). } \\
\text { Social psychology } \\
\text { HQ-The Family. Marriage. } \\
\text { Women } \\
\text { HT_Communities. Classes. } \\
\text { Races (7) }\end{array}$} & Sociology. Social psychology & 2 \\
\hline & $\begin{array}{l}\text { Sexual life/Sexual life. Sex instruc- } \\
\text { tion and sexual ethics }\end{array}$ & 2 \\
\hline & $\begin{array}{l}\text { The Family. Marriage. Women. } \\
\text { Prostitution }\end{array}$ & 1 \\
\hline & $\begin{array}{l}\text { Communities. Classes. Races. } \\
\text { Classes. Caste system }\end{array}$ & 1 \\
\hline & $\begin{array}{l}\text { Communities. Classes. Races, } \\
\text { including race as a social group and } \\
\text { race relations in general }\end{array}$ & 1 \\
\hline
\end{tabular}

of study through a series of databases and spreadsheets that interlink recent research articles from Field X, information about the methodology of these articles, bibliographical information about the citations used in these articles, and LC class letters pertaining to these citations.

In this way, a reference librarian could select an LC class description that intrigued her or him from these tables, be linked to the relevant citation, and then examine the article from which the citation was taken in order to see how a tourism scholar incorporates intellectual insights from a specific LC class or subclass into her or his own research work.
The librarian would read the article in question, paying special attention to the appearance of the relevant citation and noting how that citation advances the argument of the article as a whole. This strategy allows the reference librarian to gain a better understanding of tourism research in general, leading to better reference service for students and faculty in tourism departments.

The authors provide some examples of how this process works. For example, a librarian interested in how quantitative tourism researchers (table 9) make use of LC class BF (psychology) might choose an item classified in LC as "Affection. 


\begin{tabular}{|c|c|c|}
\hline \multicolumn{3}{|c|}{$\begin{array}{c}\text { TABLE } 11 \\
\text { Examples of Nontourism Disciplines and Fields of Study from Which } \\
\text { Theoretical or Review Articles Draw Their Citations (104) }\end{array}$} \\
\hline $\begin{array}{l}\text { LC Main Class/Subclass } \\
\text { Letters \& Selected Class/ } \\
\text { Broad Subclass Titles }\end{array}$ & $\begin{array}{c}\text { Description of Disciplines/Fields } \\
\text { of Studies Based on LC Class/ } \\
\text { Subclass Titles }\end{array}$ & $\begin{array}{l}\text { Number of Citations } \\
\text { from LC Class/ } \\
\text { Subclass }\end{array}$ \\
\hline \multirow{4}{*}{$\begin{array}{l}\text { GF-Human ecology. } \\
\text { Anthropogeography } \\
\text { GN-Anthropology (9) }\end{array}$} & Human ecology. Anthropogeography & 1 \\
\hline & $\begin{array}{l}\text { Anthropology. Ethnology. Social and } \\
\text { cultural anthropology. Applied anthro- } \\
\text { pology }\end{array}$ & 6 \\
\hline & $\begin{array}{l}\text { Anthropology. Ethnology. Social and } \\
\text { cultural anthropology. Cultural traits, } \\
\text { customs, and institutions. Economic } \\
\text { organization. Economic anthropology }\end{array}$ & 1 \\
\hline & $\begin{array}{l}\text { Anthropology. Ethnology. Social and } \\
\text { cultural anthropology. Culture and } \\
\text { cultural processes, including social } \\
\text { change, structuralism, diffusion, etc. }\end{array}$ & 1 \\
\hline \multirow{5}{*}{$\begin{array}{l}\text { B-Philosophy, Psychol- } \\
\text { ogy, Religion } \\
\text { BD, BF, BL (8) }\end{array}$} & Philosophy & 4 \\
\hline & $\begin{array}{l}\text { Speculative Philosophy. Epistemology. } \\
\text { Theory of knowledge }\end{array}$ & 1 \\
\hline & Psychology. Consciousness. Cognition & 1 \\
\hline & Psychology. Psychoanalysis & 1 \\
\hline & Religion & 1 \\
\hline \multirow{6}{*}{$\begin{array}{l}\text { QA-Mathematics } \\
\text { SB-Plant culture } \\
\text { T-Technology (General) } \\
\text { TL-Motor vehicles. } \\
\text { Aeronautics. Astronautics } \\
\text { TX-Home economics } \\
\text { UF-Artillery (8) }\end{array}$} & $\begin{array}{l}\text { Mathematics. Instruments and } \\
\text { machines. Electronic computers. Com- } \\
\text { puter science }\end{array}$ & 2 \\
\hline & $\begin{array}{l}\text { Agriculture. Plant culture. Parks and } \\
\text { public reservations. Including theory, } \\
\text { management, history }\end{array}$ & 1 \\
\hline & Technology (General). & 1 \\
\hline & $\begin{array}{l}\text { Motor vehicles. Aeronautics. Astro- } \\
\text { nautics. Aeronautics. Aeronautical } \\
\text { engineering }\end{array}$ & 1 \\
\hline & $\begin{array}{l}\text { Home economics. Hospitality industry. } \\
\text { Hotels, clubs, restaurants, etc. Food } \\
\text { service }\end{array}$ & 2 \\
\hline & $\begin{array}{l}\text { Military Science. Artillery. Ordnance } \\
\text { material (Ordnance proper) }\end{array}$ & 1 \\
\hline \multirow{3}{*}{$\begin{array}{l}\mathrm{N} \text {-Visual arts } \\
\mathrm{PN} \text {-Literature (General) } \\
\text { (4) }\end{array}$} & Fine Arts. Visual arts. History & 2 \\
\hline & $\begin{array}{l}\text { Language and Literature. Literature. } \\
\text { Drama. Broadcasting. Television } \\
\text { broadcasts }\end{array}$ & 1 \\
\hline & $\begin{array}{l}\text { Language and Literature. Literature. } \\
\text { Literary history. Modern }\end{array}$ & 1 \\
\hline
\end{tabular}


Feeling. Emotion." This is linked to a citation from a book entitled The Nature of Prejudice by Gordon Allport, which in turn is linked to an article by Abraham Pizam, Natan Uriely, and Arie Reichel. ${ }^{41}$ Pizam et al. use Allport, among others, to talk about the degree to which long-term working tourists on an Israeli kibbutz adhere to the "contact model" of the Social Psychology of Intergroup Conflict theory, which states that "intergroup contact will lead to change in mutual attitudes and relations of the interacting members ..., enhancing understanding and acceptance among the interaction group members, and consequently reduc[ing] intergroup prejudice, conflict, and tension." 42 The librarian would thus become aware that some tourism researchers are heavily involved in viewing tourist-host interactions from psychological perspectives. The same librarian may become intrigued with how LC class KZ (Law of Nations), which is linked to a citation from James Hannon's Ph.D. dissertation (classified as "International Law and other disciplines") contained in an article by Nancy Gard McGehee, was used. ${ }^{43}$ McGehee, a sociologist by training, was interested in understanding how insights from self-efficacy, resource mobilization, and network analysis theories could be used to explain the way in which participation in environmental tourism activities led to greater participation in large-scale social movements. She thus relied heavily on Hannon's work about the nature of the "commitments, affiliations, and subjective identities" that led individuals to join international peace movements protesting what they considered to be imperialist foreign policies and laws. ${ }^{44}$ After examining the use made of this citation, the librarian knows that some tourism scholars see tourist activities, especially those that create powerful network ties, as good predictors of future political and social activism - a phenomenon that can be validated by examining why individuals became members of political parties, social movements, and national protest groups.

With regard to qualitatively based research articles (table 10), a librarian might become interested in LC class HT (Communities. Classes. Races), which is linked to Louis Dumont's book Homo Hierarchicus: The Caste System and Its Implications, which in turn is linked to an article by Sharon J. Hepburn. ${ }^{45}$ Hepburn, using theories from Ludwig Wittgenstein and Peter Winch stating that any "action (as meaningful behavior) must be interpreted and understood in the terms through which the actor conceives of it," ${ }^{46}$ has suggested, through her reading of Dumont and others, that Nepalis comprehend tourists through a perspective of caste and ethnicity, differentiating among them on the basis of "essential qualities" and characteristics. ${ }^{47}$ Hepburn's use of Dumont's classic work thus alerts librarians that sociological insights of the kind provided by Winch and Dumont are relevant for tourism researchers, especially those who want to see tourism not from the Western gaze but, rather, from the perspective of "host gaze" - "the person whose labor has become a spectacle." 48

Alternatively, a librarian might want to know about the use made of LC class E (History of America), linked to a book chapter by Jean Barman, Yvonne Hebert, and Don McCaskill (classified in "Indians of North America"), which was cited by Yiping $\mathrm{Li}^{49} \mathrm{Li}$, talking about the challenges faced by a Saskatchewan (Canada) heritage park, placed tourism marketing issues within the context of the history of native education. Natives who were brought up in an "institutionalized European school system" and natives who were brought up with a more traditional ceremony-based teaching approach are 
two very distinct groups of people with two worldviews. ${ }^{50}$ Using historical sources such as Barman, Hebert, and McCaskill, Yi alerts us to the fact that tourism attractions are often the sites of ideologically based cultural clashes that have significant implications for their future development and viability. This example tells the librarian that tourism research frequently benefits from an examination of sociocultural and historical contexts: how has a particular historical factor shaped a current tourism-based phenomenon?

Finally, glancing at the citations used in theoretical and review research (table 11), a librarian might look more closely at LC class GN (Anthropology), focusing, for example, on the items classified in "Ethnology." One of these is a citation from Margery Wolf's book A Thrice Told Tale: Feminism, Postmodernism and Ethnographic Responsibility, which is linked to an article by Tazim Jamal and Keith Hollinshead. ${ }^{51}$ Here, the librarian would learn much about why tourism research should focus on "the total context rather than on the forms of tourism or the individual tourist [because] in the context may be found inequities of wealth and power that invoke transformations of the native self and identity, as the collective history of those upon whom the visually oriented tourist gaze befalls metamorphoses ambiguously." ${ }^{52}$ As support for their argument, Jamal and Holinshead turn to Wolf, who warns "feminist anthropologists [to] not become distracted by the engagement of many postmodernist observers with form to the extent of neglecting the political agenda of the topic." 53

Why is such knowledge important for librarians? As Lynn Westbrook has observed in her study of the information needs of women's studies researchers-by definition a highly interdisciplinary and multidisciplinary group of individu- als - such scholars say that, in the early stages of their work, "concrete support in exploring the issue at hand would be most helpful." ${ }^{54}$ More specifically, they assert that "I need a librarian to ask questions to get me to see my research focus in a different light" or a librarian who can help find "[a] way to conceptualize my problem ... talking through the idea and getting her response and knowledge." ${ }^{55}$ Summarizing her findings, Westbrook remarks that "librarians who are able to partner with, rather than serve, faculty are in a stronger position to support research." ${ }^{\prime 56}$ Urging librarians not only to take the time to find about the various individual research agendas of interdisciplinary faculty members, but also about the wide range of theories used by them, she suggests that reference questions not be approached as discrete one-time events. Rather, the librarian who is committed to providing excellent reference service to interdisciplinary researchers should know how to make connections from a single reference question to larger "issues pertinent to the research agenda" of that particular scholar.

In many ways, these are imposing and daunting demands to place on librarians. Yet, for many interdisciplinary scholars faced with navigating numerous fields and subfields in which they may not have received formal training, a librarian who can provide insight and knowledge about the interconnections between and among disciplines and fields of study can be a crucial ally. One way that librarians can become such an ally is to make a rigorous study of the citation characteristics of an interdisciplinary field such as tourism studies, or any other field, because the method described here is generalizable. An extensive analysis of citation patterns along the lines discussed above draws a detailed intellectual map of a field - a map that provides key informa- 
tion, through LC classification schedules, about the diverse range of subject areas used by interdisciplinary scholars in their research work. It allows librarians to see the relationship of certain LC classes and subclasses (and therefore various disciplines and fields of study) to broad types of research methodologies. Finally, it allows librarians to make a detailed examination about the way in which individual citations from selected disciplines function in the context of an individual research article, something that can make a librarian into an astute research associate for faculty members rather than just a finder of isolated bits of information. In sum, these various kinds of knowledge, gained through analysis of citation patterns, can become the foundation for offering the type of partnershipbased library service, whether in the area of collection development or reference service, that interdisciplinary scholars increasingly demand.

In theoretical terms, analysis of citation characteristics can help librarians cope with information scatter by concretely identifying the obscure places where needed information is dispersed. As more and more disciplines move toward interdisciplinarity and multidisciplinarity, the problems associated with information scatter will only increase. Librarians who make an analysis of the citation characteristics of a field in the way described here can ensure that they are ready to face the challenges of information scatter by being more confident in their knowledge about the intellectual structure of interdisciplinary and multidisciplinary fields. They will not only be more confident that their library's collection is well stocked with the titles needed by a specific interdisciplinary scholar, but they also will be able to ask the types of questions that cause scholars to conceptualize issues in new ways or to see their "research focus in a different light." ${ }^{57}$ Certainly, the method outlined here represents a considerable amount of detailed work and analysis. The question of practicality naturally arises: who has the time, or the inspiration, to undertake such a task ${ }^{58}$ This is the wrong question to ask. Instead of seeing this method as an onerous burden, it should be regarded as a key element of a re-intellectualized approach to librarianship-an approach that emphasizes subject-specific knowledge that can be of lasting value rather than increasingly deintermediated process-based skills.

\section{Conclusion}

As Katherine Corby points out, librarians have often analyzed citations in order to generate journal core lists. ${ }^{59}$ After surveying a number of such studies, she concludes that results have been mixed. Faculty members, especially in interdisciplinary fields such as women's studies, have very different ideas about the journals that are most useful to them. When Thura Mack compiled the answers of twenty-five women's studies professors who were asked to list the six journals most useful to them in their work, she discovered that just under 85 percent of the journals were named only once. ${ }^{60}$ The findings of Kathleen E. Joswick and Jeanne Koekkoek Stierman, as well as Larry Hardesty and Gail Oltmanns, are also revealing. ${ }^{61,62}$ After analyzing the citations in undergraduate student term papers, both sets of scholars found that undergraduates overwhelmingly used only journals available at their institutional libraries. This phenomenon, as Corby observes, may be viewed as "the 'self-fulfulling prophecy' syndrome": librarians who rely on core journal lists for selection and deselection purposes contribute to a situation where those core journals are the only ones being used..$^{63}$ On the one hand, faculty cannot agree 
which journals are core journals. On the other hand, librarians nevertheless use a variety of methods (e.g., ISI Journal Citation Reports) to identify some journals as core, with the understanding that noncore items will be cancelled or not purchased. Undergraduates then rely almost exclusively on the core items in their term papers and assignments, whether or not all faculty members consider them to be core. As John M. Cullars pointed out in a discussion of the citation characteristics of English-language philosophy monographs, "extreme scatter of serial citations in philosophy strongly suggests that no core collection of journals can adequately serve user needs." ${ }^{\prime 64}$

The construction of core journal lists (or core book lists) in various fields is thus problematic. To be sure, it is a necessary first step, one that can identify lacunae in library holdings. ${ }^{65}$ But, as described above, the universities that employ tourism scholars who frequently publish in tourism research journals own a very large proportion of the core tourism research literature identified in table 4 . Thus, they already do a good job of collecting the core sources in the interdisciplinary field of tourism studies. But collecting core materials in a field is not the same as having librarians who can work in partnership with scholars to conceptualize issues in new ways or to see their "research focus in a different light." Something more is needed.

Analyzing the citation characteristics of a particular field with regard to source type, languages, and dates of cited items is a good next step: a great deal of extra information is thereby provided. Cullars has been adept at such research, examining citation patterns of Italian and Spanish literary monographs, French and German literary monographs, French and German fine arts monographs, and philosophy monographs, among others. ${ }^{66-69}$ His analysis of philosophy monographs is perhaps the most valuable of these efforts as it identifies, in broad terms, the disciplines outside philosophy that are cited in philosophy monographs ${ }^{70}$ and concludes by declaring that "more attention might profitably be paid to the frequently cited disciplines outside of philosophy." addition, he identified various schools of philosophy and hinted that citation patterns may differ in philosophical works written by female scholars, especially those working in feminist philosophy. ${ }^{72}$ In the end, however, such research tends to become overly mechanical. Something still more is needed.

Stephen E. Wiberley Jr., in an analysis of fifty-four literary studies and art monographs, identifies five types of scholarship present in these two humanities fieldsdescriptions of primary sources, editing of primary sources, historical studies, criticism, and theory-and argues that each of these five types conforms broadly to a specific bibliometric model. ${ }^{73}$ When that bibliometric model has been defined and when a librarian can associate a scholar with a particular model, the librarian can better understand - and thus better help - that scholar. For example, a librarian will know that "an interpretative literary scholar" will not only use archives and manuscripts but will "also use many sources that class outside traditional literature (nontheoretical LC classification PA-PZ), an unusually large proportion of sources that class in C-F, relatively few recent sources, and relatively little theory." ${ }^{\prime 4}$ Although Wiberley's study has an astounding number of methodological flaws that undermine his conclusions about arts and literary studies scholarship, his general observation that the diverse subareas, specialties, and subtypes of various academic fields may be correlated with distinct citation patterns is a sound one. 
Working independently of, and with no knowledge of, Wiberley's work, the authors of this study examined the interdisciplinary social sciences field of tourism studies from a perspective similar to his, hypothesizing that the type of methodological approach used by tourism scholars - whether quantitative, qualitative, or theoretical/review - would affect the type of LC class areas/LC disciplinary areas cited in published articles using that approach. As shown in table 8, this hypothesis was justified: qualitatively based and theoretical/review-based tourism articles have a substantially larger percentage of citations from LC fields external to tourism itself than do quantitatively based articles, with articles employing a mix of qualitative and quantitative methods falling somewhere between the two. Moreover, different methodological approaches give rise to different emphases in the LC ranges of citations within articles employing those approaches. (See examples in tables 9 through 11.) Librarians who can identify the methodological approach used by a specific tourism studies scholar can thus gain additional insight about what LC subject areas that scholar would typically cite in her or his research. As has also been demonstrated above, an added benefit of correlating LC classes and subclasses with methodological approaches is that librarians can make a detailed examination about the way in which individual citations from selected LC classes and subclasses function in the context of an individual research article. In this way, librarians can truly become research partners capable of generating fresh research approaches that may be of service to scholars in an interdisciplinary field. The notion that "there is little justification for librarians to tell critics or theorists what they should read"75 may be an outdated one, especially given the comments of women's studies scholars quoted by Westbrook.
Using the interdisciplinary field of tourism studies as an example, this article has outlined a comprehensive approach to how librarians can help interdisciplinary scholars in their research work. The approach consists of two components: a traditional analysis of citation characteristics that generates core journal lists and core book lists as well as information about the source types and chronological periods of citations; and a detailed analysis of citations by LC classification so as to get a better sense of the information scatter typically associated with an interdisciplinary field and to gain insight into how interdisciplinary scholars do their intellectual work. This approach can be viewed as a tool that is capable of helping collection development and reference librarians gain understanding about the subject breadth of an interdisciplinary field and provide "information leeway" for interdisciplinary scholars. Cynthia Dobson, Jeffrey D. Kushkowski, and Kristin H. Gerhard noted that "collection evaluation should begin by building an information model of the interdisciplinary area that reflects both the field itself and the unique qualities of a particular program."76 A detailed breakdown of the LC classes and subclasses cited by a group of interdisciplinary scholars can contribute to the development of such an information model. This knowledge then can be used to create tools that function as the kind of "information leeway" that interdisciplinary scholars crave-tools that such scholars say should provide an "applicable 'smattering' of relevant material" and "a small percentage, some suitable subset of research in subject areas related to my work."77 For instance, as Joan B. Fiscella stated, despite the ready availability of electronic catalogs and indexes, bibliographies covering interdisciplinary areas can be invaluable for individual scholars who identify "a 
potentially useful theory or framework outside [their] specialization." ${ }^{\prime 78}$ As well, an analysis of this kind would allow librarians to participate as full members of interdisciplinary research teams, as envisioned, for example, by Jack T. Smith Jr.. ${ }^{79}$ In sum, detailed analysis of citation characteristics from the perspective of LC classes and subclasses can help librarians build up a body of knowledge about, and expertise in, a given interdisciplinary field or area, allowing them to become the type of valued intermediaries that scholars look for when they are probing and exploring unfamiliar academic subjects and areas.

\section{Notes}

1. Don Spanner, "Border Crossings: Understanding the Cultural and Informational Dilemmas of Interdisciplinary Scholars," Journal of Academic Librarianship 27 (Sept. 2001): 352-60.

2. Carole L. Palmer and Laura J. Neumann, "The Information Work of Interdisciplinary Humanities Scholars: Exploration and Translation," Library Quarterly 72 (Jan. 2002): 99.

3. Palmer, "Structures and Strategies of Interdisciplinary Science," Journal of the American Society for Information Science 50 (1999): 252.

4. Palmer and Neumann, "The Information Work of Interdisciplinary Humanities Scholars," 99, 102, 103.

5. Palmer, "Structures and Strategies," 251.

6. Susan E. Searing, "Meeting the Information Needs of Interdisciplinary Scholars: Issues for Administrators of Large University Libraries," Library Trends 45 (fall 1996): 315-42. See also Michael F. Winter, "Specialization, Territoriality, and Jurisdiction: Librarianship and the Political Economy of Knowledge," Library Trends 45 (fall 1996): 343-63.

7. Ibid., 251.

8. Lynn Westbrook, "Information Needs and Experiences of Scholars in Women's Studies: Problems and Solutions," College \& Research Libraries 64 (May 2003): 197.

9. Ibid., 203.

10. Ibid., 203.

11. Charlotte M. Echtner and Tazim B. Jamal, "The Disciplinary Dilemma of Tourism Studies," Annals of Tourism Research 24 (1997): 868.

12. Jafar Jafari, "Retracing and Mapping Tourism's Landscape of Knowledge." Available online at http://www.fas.harvard.edu/ drclas/publications/revista/Tourism/jafari.html [Accessed 9 July 2003].

13. __ "Research and Scholarship: The Basis of Tourism Education," Journal of Tourism Studies 1 (1990): 33-41.

14. Nelson H. H. Garburn and Jafar Jafari, "Introduction: Tourism Social Science," Annals of Tourism Research 18 (1991): 7-8.

15. See the special issue of Annals of Tourism Research 18 (1991): 1-169, which contains ten essays that describe how tourism intersects with ten different fields to form a multidisciplinary social science.

16. The debate is conveniently summarized in Echtner and Jamal, "The Disciplinary Dilemma of Tourism Studies," 868-83. See also John Tribe, "The Indiscipline of Tourism," Annals of Tourism Research 24 (1997): 638-57.

17. See, for example, Roger W. Riley and Lisa L. Love, "The State of Qualitative Tourism Research," Annals of Tourism Research 27 (2000): 164-87.

18. See, for example, R. W. Carter, G. S. Baxter, and M. Hockings, "Resource Management in Tourism Research: A New Direction?" Journal of Sustainable Tourism 4 (2001): 265-80.

19. See, for example, Kristin Gerhard, Mila Su, and Charlotte Rubens, "An Empirical Examination of Subject Headings for Women's Studies Core Materials," College \& Research Libraries 59 (Mar. 1998): 130-38; Hur-Li Lee, "Collection Development as a Social Process," Journal of Academic Librarianship 29 (Jan. 2003): 23-31; Westbrook, "Information Access Issues for Interdisciplinary Scholars: Results of a Delphi Study on Women's Studies Research," Journal of Academic Librarianship 23 (May 1997): 211-16.

20. See The ISI Database: The Journal Selection Process. Available online at http://www.isinet. com/isi/hot/essays/selectionofmaterialforcoverage/199701.html [Accessed 21 June 2003].

21. Tourism scholarship itself agrees that Annals of Tourism Research and Tourism Management are two of its central journals, ranking them number one and number three, respectively. Journal of Travel Research (JTR) is ranked number two but is not included in Journal of Citation Reports. See Richard M. Howey, Kathryn S. Savage, Marja J. Verbeeten, and Hubert B. Van Hoof, "Tourism and 
Hospitality Research Journals: Cross-citations among Research Communities," Tourism Management 20 (1999): 133-39; Pauline J. Sheldon, "Journal Usage in Tourism: Perceptions of Publishing Faculty," Journal of Tourism Studies 1 (1990): 42-48.

22. In the case of $A T R$, the authors examined the twelve issues comprising volumes 27 through 29. In the case of $T M$, the authors examined the eighteen issues comprising volumes 21 through 23.

23. Country of origin of authors, as shown in author affiliations, is as follows for ATR: United States (61); Australia (35); United Kingdom (32); New Zealand (16); Israel (15); Canada (11); The Netherlands (10); Spain (8); Denmark (6); and Norway (5). For TM, country of origin of authors is as follows: United Kingdom (57); United States (53); Australia (40); New Zealand (20); Hong Kong (16); Taiwan (16); South Korea (15); Spain (12); Canada (10); Israel (9); Turkey (7); and Singapore (5). These numbers do not necessarily coincide with the number of authors for the articles in question because some authors have double affiliations, either within the same country or with two institutions in different countries. Double affiliations are counted twice. For example, if the author is affiliated with two different institutions in Taiwan, Taiwan is counted twice. These numbers are based on all 142 research articles in ATR and all 149 research articles in TM.

24. This information was derived from the geographic keyword(s) assigned to ISI article records. If a geographic keyword was not assigned, the authors examined other parts of the record, and if necessary the whole article, to extract the required information.

25. To determine broad research types, the abstract and methodology sections of each selected article were examined for specific details about the research methodology. If this proved insufficient, the entire text of the article was examined. Specific research methodologies were as follows: theoretical analysis/review; case study; content analysis; content analysis and secondary data analysis; content analysis, ecological traverse, interview, and observations; data modeling; data modeling and secondary data analysis; ethnography; secondary data analysis; survey; survey and interview; survey and secondary data analysis; survey, interview, and secondary data analysis; survey, interview, and observations; survey, interview, and focus groups; survey and focus groups; interview; interview, focus groups, and grounded theory; interview, field notes, documents, and case study. These specific methodologies were then grouped into four broad research types.

26. In the course of the sampling process, a number of problems with ISI indexing were identified. For example, some citations listed by ISI were not present in the original article; if the erroneous citation happened to be sampled, it was replaced with the next citation found in the reference list of the original article. In other instances, the author's last name was provided correctly by ISI, but the author's initials and/or the source title was incorrect. In these cases, the authors chose the citation for the author with the same last name in the original article. The order of citations in ISI records does not necessarily correspond with the order of citations in full-text articles.

27. Sample size was calculated using the Sample Size Calculator provided by Creative Research Systems. Available online at http://www.surveysystem.com/sscalc.htm [Accessed 15 March 2003].

28. Available online at http://www.randomizer.org [Accessed 15 March 2003].

29. If necessary bibliographic information could not first be found in OCLC, other catalogs, including those of the Library of Congress and major North American universities, were searched in order to find the needed information. For very obscure items, classifications were assigned using LC schedules.

30. Each citation was categorized as one of the fifteen following types of sources: book; edited book; conference proceedings (if published or unpublished conference proceedings were referred to as a whole); Ph.D. dissertation; master's thesis; report/statistics (for government publications and publications issued by public/private organizations that focused specifically on statistics, project reports, development plans, statistical summaries, rules and regulations, censuses, statistical abstracts, etc.); book chapter; conference paper (if a specific conference paper, whether published or unpublished, was referred to); electronic resource; broadcast; academic/scholarly journal; trade publication; consumer magazine; newspaper; and newsletter. Types of periodical publications were determined based on classification provided in Ulrich's Periodical Directory. Available online at http://www.ulrichsweb.com/ulrichsweb/ [Accessed 15 January 2003].

31. One or two letters designating either the main class or the first subclass (e.g., G, GV, HQ) of the LC classification were recorded for each item. For the most part, these classifications were available from OCLC records, but occasionally other major university catalogs were used to track down obscure items.

32. These nine categories are: academic/scholarly journal; book and edited book; book chapter; report/statistics; consumer magazine/trade publication/newsletter; conference paper/conference proceedings; newspaper (print \& online) and broadcast; Ph.D. dissertation/master's thesis; and electronic resource. 
33. Percentages for TM do not add to 100 because of rounding (99.9). (41).

34. Data are as follows: 1993 (43 citations); 1994 (40); 1995 (48); 1996 (36); 1997 (38); 1998

35. Full bibliographic information for the fourteen books is as follows: Valene L. Smith, Hosts and Guests: The Anthropology of Tourism (Philadelphia: Univ. of Pennsylvania Pr., 1989); Nelson H. H. Graburn, Ethnic and Tourist Arts: Cultural Expressions from the Fourth World (Philadelphia: Univ. of Pennsylvania Pr., 1977); Louis Turner and John Ash, The Golden Hordes: International Tourism and the Pleasure Periphery (New York: St. Martin's Press, 1975); Stephen Page and Donald Getz, The Business of Rural Tourism: International Perspectives (London: International Thomson Business Pr., 1997); Norman K. Denzin and Yvonna S. Lincoln, Handbook of Qualitative Research (Thousand Oaks, Calif.: Sage, 1994); Yvonna S. Lincoln and Egon G. Guba, Naturalistic Inquiry (Beverly Hills, Calif.: Sage, 1985); Philip Kotler and Gary Armstrong, Principles of Marketing ( ( $^{\text {th }}$ ed.) (Upper Saddle River, N.J.: Prentice-Hall, 1999); Dean MacCannell, The Tourist: A New Theory of the Leisure Class (Berkeley, Calif.: Univ. of California Pr., 1999); Stephen L. J. Smith, Tourism Analysis: A Handbook (Harlow, Essex, England: Longman Scientific \& Technical, 1995); James Gordon Nelson, R. Butler, and Geoffrey C. Wall, Tourism and Sustainable Development: Monitoring, Planning, Managing (Waterloo, Ont.: Univ. of Waterloo Department of Geography, 1993); Michel Picard and Robert Everett Wood, Tourism, Ethnicity, and the State in Asian and Pacific Societies (Honolulu: Univ. of Hawai'i Pr., 1977); Robert Woodrow McIntosh, Charles R. Goeldner, and J. R. Brent Ritchie, Tourism: Principles, Practices, Philosophies ( $7^{\text {th }}$ ed.) (New York: Wiley, 1995); Yiorgos Apostolopoulos, Stella Leivadi, and Andrew Yiannakis, The Sociology of Tourism: Theoretical and Empirical Investigations (New York: Routledge, 1996); J. R. Brent Ritchie and Charles R. Goeldner, Travel, Tourism, and Hospitality Research: A Handbook for Managers and Researchers (New York: Wiley, 1987).

36. The names of these six universities are: Virginia Tech; Texas A\&M; Northern Arizona University; University of Central Florida; University of Illinois at Urbana-Champaign; and University of Nevada at Las Vegas.

37. Jafari, "Retracing and Mapping Tourism's Landscape of Knowledge."

38. In table 5, all disciplines listed below the triple line are nontourism disciplines. There are 273 citations from these disciplines, collectively representing 48.8 percent of citations. Percentages in table 5 are based on a denominator of 559 (the total number of citations examined in the present study). The figures used in the sentence here are based on a denominator of 273 . Not all disciplines listed in this sentence appear in tables 6 and 7 because tables 6 and 7 illustrate selected disciplines only.

39. See, for example, Margaret Byrne Swain, Maryann Brent, and Veronica H. Long, "Annals and Tourism Evolving: Indexing 25 Years of Publication," Annals of Tourism Research 25 (1998): 991-1014; see also Jafar Jafari and Dean Aaser, "Tourism as the Subject of Doctoral Dissertations," Annals of Tourism Research 15 (1988): 407-29.

40. Richard M. Howey, Kathryn S. Savage, Marja J. Verbeeten, and Hubert B. Van Hoof, “Tourism and Hospitality Research Journals: Cross-citations among Research Communities," Tourism Management 20 (1999): 134.

41. Abraham Pizam, Natan Uriely, and Arie Reichel, "The Intensity of Tourist-Host Social Relationship and Its Effects on Satisfaction and Change of Attitudes: The Case of Working Tourists in Israel," Tourism Management 21 (2000): 395-406.

42. Ibid., 398.

43. Nancy Gard McGehee, "Alternative Tourism and Social Movements," Annals of Tourism Research 29 (2002): 124-43.

44. Ibid., 127.

45. Sharon J. Hepburn, “Touristic Forms of Life in Nepal," Annals of Tourism Research 29 (2002): 611-30.

46. Ibid., 614.

47. Ibid., 627.

48. Ibid., 615.

49. Yiping Li, "Ethnic Tourism: A Canadian Experience," Annals of Tourism Research 27 (2000): $115-31$.

50. Ibid., 123.

51 T. Jamal and K. Hollinshead, "Tourism and the Forbidden Zone: The Underserved Power of Qualitative Inquiry," Tourism Management 22 (2001): 63-82.

52. Ibid., 75 .

53. Ibid., 77.

54. Westbrook, "Information Needs and Experiences of Scholars in Women's Studies," 197.

55. Ibid., 203.

56. Ibid., 205.

57. Ibid., 203. 
58. The authors thank an anonymous reviewer for bringing to their attention the need to address the issue of practicality.

59. Katherine Corby, "Constructing Core Journal Lists: Mixing Science and Alchemy," portal: Libraries and the Academy 3 (2003): 207-17.

60. Thura Mack, "A Model Methodology for Selecting Women's Studies Core Journals," Library $\mathcal{E}$ Information Science Research 13 (1991): 131-45. Cited in Corby, "Constructing Core Journal Lists," 209.

61. Kathleen E. Joswick and Jeanne Koekkoek Stierman, "The Core List Mirage: A Comparison of the Journals Frequently Consulted by Faculty and Students," College E Research Libraries 58 (Jan. 1997): 48-55. Cited in Corby, "Constructing Core Journal Lists," 212.

62. Larry Hardesty and Gail Oltmanns, "How Many Psychology Journals Are Enough? A Study of the Use of Psychology Journals by Undergraduates," Serials Librarian 16, no. 1/2 (1989): 133-53. Cited in Corby, "Constructing Core Journal Lists," 212.

63. Corby, "Constructing Core Journal Lists," 212.

64. John M. Cullars, "Citation Characteristics of English-Language Monographs in Philosophy," Library E Information Science Research 20 (1998): 41-68.

65. See, for example, Jeffrey D. Kushkowski, Kristin H. Gerhard, and Cynthia Dobson, "A Method for Building Core Journal Lists in Interdisciplinary Areas," Journal of Documentation 54 (Sept. 1998): 477-88. See also Philip M. Davis, "Where to Spend Our E-journal Money? Defining a University Library's Core Collection through Citation Analysis," portal: Libraries and the Academy 2 (2002): 155-66.

66. Cullars, "Citation Characteristics of Italian and Spanish Literary Monographs," Library Quarterly 60 (Oct. 1990): 337-56.

67. _Citation Characteristics of French and German Literary Monographs," Library Quarterly 59 (Oct. 1989): 305-25.

68. _Citation Characteristics of French and German Fine Arts Monographs," Library Quarterly 66 (Apr. 1996): 138-60.

69. "Citation Characteristics of English-Language Monographs in Philosophy."

70. Ibid., 51 .

71. Ibid., 65.

72. Ibid., 58-60, 65.

73. Stephen E. Wiberley Jr., "A Methodological Approach to Developing Bibliometric Models of Types of Humanities Scholarship," Library Quarterly 73 (Apr. 2003): 121-59.

74. Ibid., 153.

75. Ibid., 152.

76. Dobson, Kushkowski, and Gerhard, "Collection Evaluation for Interdisciplinary Fields," 279-84.

77. Palmer, "Structures and Strategies of Interdisciplinary Science," 251-52.

78. Joan B. Fiscella, "Bibliography as an Interdisciplinary Information Service," Library Trends 45 (fall 1996): 293.

79. Jack T. Smith Jr., "Meta-Analysis: The Librarian as Member of an Interdisciplinary Research Team," Library Trends 45 (fall 1996): 265-79. 